\title{
Wage Productivity and Wage Income Differential in Labor Market: Evidence from RMG Sector in Bangladesh
}

\author{
Md. Gazi Salah Uddin \\ School of Business \\ Presidency University \\ 11A, Road: 92, Gulshan-2, Dhaka-1212, Bangladesh \\ Email: rimsust2002@yahoo.com
}

\begin{abstract}
Labor Market outcomes in Bangladesh at different stages of industrialization need not be similar as behavioral rationality of economic agents depends on the market context. This paper examines the issues related to wage income differentials in RMG sector. In fact wage determination behavior during the last two decades did not follow one of the basic premises in the theory of labor market in economics. In general, employment and wage determined by the marginal productivity of labor in value term. Labor Market outcomes in Bangladesh at different stages of industrialization need not be similar as behavioral rationality of economic agents depends on the market context. Women are increasingly becoming visible in the productive labor force in Bangladesh. The surplus labor is expected to take in the family farms in the rural areas and in other informal enterprise. During the last two decades, rapid changes had taken place in this scenario. Women's employment in garment factories is one of these changes. The garment sector is rapidly rising in the country since the 1980's. The paper is based survey findings conducted among the woman's workers of RMG industries located at Dhaka and Narayangong - the second largest hub of RMG factories in Bangladesh. The study was conducted on 200 female garment workers of 20 garment industries. This paper investigates the existing labor market and status of women workers in the context of wage discrimination based on gender, obstacles of work place environment in and outside of the industries. The study also analyzes the socio economic status of the women workers in the export-oriented industries like Ready Made Garments. In terms of social and economic context, that women's working condition is not favorable for the work place.

The study shows that distribution of labor force by two main sector agriculture and non-agriculture shows that during the period of 1990-91 to 1999-2000 there has been a small decline in the share of agriculture in total employment. It should be pointed out that the decline in the share of agriculture is more or less continuous for male labor force. Women contributed to 37.9 percent and 39.3 percent of employment in the manufacturing sector in 2000 and 2003 respectively. The garment sector is dependent on female labor largely because underemployment is high among women. In the urban area, the shares of women and man skilled are 12 percent and 35 percent respectively. Empirical result also shows that both the male and female labor force participation is higher in Bangladesh compare to the South Asian Countries.
\end{abstract}

Keywords: Labor market, Ready-made garments, Least developing countries

\section{Introduction}

The paper is to examine the issues related to wage-income differential in Bangladesh Labor Market. Wage determination behavior during the last two decades did not follow one pf these basic premises in the theory of labor market in economics. Employment and wage is determined by marginal productivity of labor in value term. Women are increasingly becoming visible in the productive labor force in Bangladesh. Unemployment is considered as major problem in Least Developing Countries (LDCs) like Bangladesh. The surplus labor is expected to take in the family farms in the rural areas and in other informal enterprise. During the last two decades, rapid changes had taken place in this scenario. Women's employment in garment factories is one of these changes. The garment sector is rapidly rising in the country since the 1980's. The garment sector has ensured huge employment opportunity for women, which stands an estimated rate of 70.8 percent of the total employed population in this sector (Sobhan and Khundker, 2001).

Labor market discrimination not only lowers the wages of the disadvantaged group but also results in higher pay for other groups (Oaxaca and Ransom 1994). In a Least Developing country like Bangladesh, discrimination against vulnerable groups may deeper inhuman misery and therefore policy action is vital to reduce it. The literature is extensive in the developed country, but attention to the area in the developing country perspective is scant but increasing. Many developing countries lack of information on the magnitude and dimension of discrimination, Bangladesh is one of them. 
Export oriented industrialization has emerged as a significant factor in the industrialization programmes of several Asian countries during the 1970s and the 1980s (Lee, 1984). It has been found that there are certain universal regularities in the composition of export manufacturers and related pattern of labor use by gender (UN, 1995). The garment sector is the single highest contributor in the earnings of foreign currency. Since, the sectors are labor intensive, the availability of cheap labor especially female labor, in Bangladesh has lured the national and international entrepreneurs to establish Ready Made Garments industries (RMG) here. However, some gender specific dimensions of labor exploitation have also encouraged the employers to employ a huge number of female workers in RMG sector.

Studies concerning least developing countries have found considerable sex discrimination (Ashenfelter and Oaxaca, 1991) .Earning differences between males and females result from both occupational segregation and pay differences within the same occupation. Alam et al (2004) suggested regulatory measures and its strict implementation and monitoring by the government agency that could overcome work place in security problem of female garment workers in Bangladesh. Halim and Kabir (2005) revealed that the oppressive nature of the employment generation in the RMG sector basically women are exploited due to lack of technical knowledge and training.

Two factors, which played important roles in the growth of the RMG industry in Bangladesh, were; low wages of Bangladesh and a favorable exporting environment created by the MFA Quota system. The experiences of the early exporting countries indicating that the increasing cost competition in the export markets lead entrepreneurs to search for newer source of cheap labor. In this country, women are vulnerable group of people, are likely to be affected more adversely. Therefore, women's are ready to work for low wages and for longer hours under exceedingly inhospitable conditions of work. Their 'oriental docility' normally does not let them join unions and agitate against the management (Standing, 1989; Barbezat, 1993; Lim, 1984). Women are ignored socially, neglected politically, deprived legally, exploited economically and oppressed religiously (Halim, 2001). The early decades of the twentieth century, most of the female workforce in the garment industry was made up of young single women from the rural areas for which the only alternative employment was domestic service (Kabeer, 2000). Women working in the garment sector have migrated from rural areas. The growth of the RMG sector has provided an unprecedented employment opportunity for women (Paul Muzumder, 2000). Cohen and House (1993) found that occupational segregation rather than pay discrimination was primarily to blame for gender differentials in wages in the urban labor market. The situation may be worst in the informal rural labor market, which are characterizing by unskilled labor.

\section{Objective and methodology}

The paper is to explore whether there any wage discrimination between male and female workers in the RMG sector of Bangladesh. This paper also investigates the existing labor market and status of women workers in the context of wage discrimination based on gender, obstacles of work place environment in and outside of the industries. Considering the amount of contribution in the export volume major sectors such as Ready Made Garments (RMG) would be chosen for the evidence. The paper investigates the gender differentials in wages in RMG labor market. The questions addressed in this paper are:

\section{Are wages lower for females?}

\section{Are wage discrimination due to discrimination or productivity?}

Research questions that are addressed in this study have been answered through systematic process of identification of data requirement, sources of data and method of analysis and possible outcome of the analysis. The study made use of both the information available from secondary sources. Secondary information included published reports monographs, books, websites, articles databases, newspaper reports etc. Tables from national labor force survey reports will be used. The study will also carry out intensive statistical analysis of household level data of the last two rounds of the labor force survey (LFS) of Bangladesh Bureau of Statistics (BBS) (Conducted in 1999-2000 and 2002-2003).

The study was also conducted on 200 garment workers of 20 garment industries located in Dhaka and Narayangonj - the second largest hub of RMG factories in Bangladesh. In this study, female respondents were chosen positively as they are harassed more than male workers in their workplace. The respondents have been asked to give their opinion on the social environment in and outside of their workplace with the help of the structured interview schedule. Due to the difficulties of accessing, those in their workplace the interviews have been collected from door to door conduction and appointment with the workers. In this paper the discussion has been covered with the brief description of the factory profile to workplace security, work environment, labor market. The subsequent discussion shed light on the respondent's profile and their workplace security (Alam et al 2004). The objectives of the paper is to explores whether women's workers have secure environment in the garment sector and is there any wage discrimination between male and female workers in the RMG sector of Bangladesh. This paper also investigates the existing labor market and status of women workers in the context of wage discrimination based on gender, obstacles of work place environment in and outside of the industries

Considering the amount of contribution in the export volume major sectors such as Ready Made Garments (RMG) would be chosen for the evidence. Using the stratified sampling technique the data would be collected through the structured 
questionnaire from the RMG sector run by the women worker's in major two divisions like Dhaka and Narayangonj. Around 200 samples of women worker's from the major RMG sector in two divisions (Dhaka and Narayangonj) would be surveyed through the direct interview method. Looking into the population of women worker's in the above sector the size of sample for each sector (Stratum) would be determined. Hence, PPS (Probability to Proportion Sample) method for sampling would be used in taking sample from each stratum.

\subsection{Respondent's profile}

The demographic profile of the respondents shows that the majority of the workers are of the age between 22 to 25 years. The maximum age of the workers was interviewed is 47 years where as the minimum wage is 18 years. It is found that majority of the workers are unmarried and majority have secondary education The respondent's profile indicates that this is the age when a female is emotionally sensitive, sexually vulnerable and need security and protection. This is the age when they are less reactive and easily manageable.

\section{RMG in Bangladesh}

A Significant dimension in the labor integration of economics like Bangladesh has occurred in the domin of what are known as the Export Processing Zones (EPZs). Bangladesh's competitive advantages (Unskilled labor) in RMG sectors lies in the availability of cheap labor as compared to western economics and developed economics like South Korea and Japan and Germany. The imposition of quotas on clothing exports from some of the early industrializing countries in East Asia led them to search for quota-free locations to set up garment assembly plants. A significant example of this in the case of Bangladesh was Daewoo from South Korea. Daewoo met the 'quota hopping' requirement of having a product, which was not a fully Korean operation by entering into an agreement with a local firm, Desh Garments. The effectiveness of the technology transfer involved was demonstrated when, after the agreement with Daewoo was abandoned because of internal problems in Korea, production within Desh continued to grow.

From the early 1980s, Bangladesh undertook a series of economic reforms to open up its economy under the aegis of the IMF and the World Bank. A new import policy in 1982 announced an export-led growth strategy to be spearheaded by the private sector (Rashid, 2000). A number of direct export incentive schemes were put in placel while foreign direct investment was encouraged through the establishment of export processing zones outside Dhaka and Chittagong. Further incentives for stimulating investment in RMG were instituted in the early 1990s (Bhattacharya and Rahman, 2000). RMG sector from around 50 factories employing a few thousand workers in the early 1980 s to over 3,000 factories employing around 1.8 million workers by 2000. In addition about 0.2 million people are employed in other industries linked to garment manufacturing (Khundker, 2002). The share of manufacturing in GDP growth increased from 9.8 per cent at the beginning of the 1990 s to 11.4 per cent in 2000 . That this growth was largely driven by the RMG sector - which grew at a compound rate of 15 per cent per year during the 1990s (Bhattacharya and Rahman, 2000 ) - is evident from the fact that value added for total large-scale manufacturing grew at 7 per cent annually during the 1990s, but at 4 per cent when RMG was excluded (Mahmud, 2003).

In addition, a host of ancillary industries producing accessories have also emerged and grown alongside the garment industry. One estimate suggests that 80 per cent of garment accessories were locally produced, valued at $\$ 0.5$ billion a year (Bhattacharya and Rahman, 2000). As Quddus and Rashid (2000) point out, the concept of value addition takes on an additional significance in the case of exports, particularly in an industry which has to import many of its inputs, since this has a bearing on the country's foreign exchange earnings. Raw materials have to be imported both for garments and the country's small textile industry, and accounted for around three-quarters of the import of total industrial raw materials in the 1990s (Bhattacharya and Rahman, 2000). A much higher proportion of workers in these factories are male. Only 35 per cent of workers in the knitwear industry, which is more technology intensive than woven garments, are women (Chaudhuri-Zohir, 2000). This reflects the situation in other parts of the world where women lose out as manufacturing processes become more capital and/or skill intensive (Barrientos, Kabeer and Hossain, 2003) and is a point we will return to later.

\section{Labor force participation in the RMG sector}

Women's labor force participation rate increased during the 1990s while male force participate rate declined slightly. A small proportion of the female workers have been categorized as skilled. Percentage of the female workers is much smaller than male workers. Poorer women have less access to education and skill endowment. However, women from this group are more likely to take up paid employment. This implies slow improvement of educational endowment of female labor force. The number and share of women in entrepreneurial status declined during the early 1990s. Female labor force experienced a significant extent of causation during 1996-2003 periods.

\subsection{Sect oral distribution of employment}

Distribution of labor force by two main sector agriculture and non-agriculture shows that during the period of 1990-91 to 1999-2000 there has been a small decline in the share of agriculture in total employment. It should be pointed out that the decline in the share of agriculture is more or less continuous for male labor force (Table 1). The large in the number of female labor force in agriculture contributed to the reversal of the trend of agriculture's share of total labor force. There has been no significant structural change in the labor market during the periods of acceleration of economic growth. 


\subsection{Status of employment}

The sector distribution of female employment does not adequately reveal women's roles in the supply of labor in the major sectors especially manufacturing. To obtain the complete picture the women's share in total employment in manufacturing and agriculture and especially paid employment in this sector should be focused. Table-2 shows that women contributed to 37.9 percent and 39.3 percent of employment in the manufacturing sector in 2000 and 2003 respectively. The major sector is dependent on female labor largely because underemployment is high among women. Therefore, the contribution of women in terms of labor hours will be much les than the number of person involved. Women's contribution to hired employed in these sectors, particularly in manufacturing, is an important indicator of women's contribution of Bangladesh Labor market. Women's share of paid employment in manufacturing has increased, which is a positive feature of the female labor market.

\subsection{Quality of labor force}

The large companies in the garment industry workers in the lower unskilled and semi skilled categories and paid just about the statutory minimum wage, while workers in the skilled categories are paid more. The information on skill composition of the labor force have been shown in Table 3.In the rural area, 9 percent of the labor force and 37 percent of the male labor force are skilled. In the urban area, the shares of skilled are 12 percent and 35 percent respectively. Skill composition should be interpreted cautiously because skill is defined to include on the job skill attainment.

\subsection{Gender differential in wage rates}

The large majority of women regardless of whether they are employed as unskilled helpers or as skilled tailors barely receive the legally stipulated minimum wage. They are frequently to require working overtime, but since this is set against production targets, workers are not paid for overtime work. Wage difference between male and female workers prevails in most developing countries. Wage difference between male and female workers prevails in most developing countries. The ratio of female to male wage rates is expected to rise with economic growth and the expansion of employment opportunities for women. The information on wage rates in the manufacturing sector are shown in Table 4. Female wage is much lower than lower wage. This is true for all sectors. Female wage like male wage is the highest in education services.

\subsection{Social and economic factors influence the gender differential of wage}

Male and Female wage differential can be attributed to the following factors:

\section{-}

segments.
The differences in human capital endowment of male and female labor force

A differential purely due to gender

Job segmentation with women's employment being concentrated in the low productive and low wage

In the traditional economy, it is very difficult to relate wage difference with the productivity difference because most workers are unskilled and the productivity differences may not be captured by human capital variables. Society's perceptions of women's bargaining power play dominant roles in this context. An important socio-cultural factor behind the lower wage of women is the perception that women are secondary earners. The perception of women are secondary earners also influences the institutional wage setting process. Male and female wage differentiation, which is apparently link with pure gender bias, reflects the lower bargaining power in the society. Women without male earner in the household are required to earn to ensure survival and many women have to earn to save for dowry that they will pay to their husband.

\subsection{Growth of labor force}

Table-5 presents data on the growth of labor force and employment during the period of 1991-2003 for which comparable data are available. The increase in the pace of growth of labor force are at population in the labor force age, which in turn has been associated with higher population growth rates during the 1970s nd early 1980s. A positive employment growth is shown by data presented in table-, there is a sharp difference in the picture of male and female labor force. Growth of female labor force and employment is much higher during both sub-periods. This conjecture implies that the decline of male labor force growth in 1996-2000 is likely to be reflections of the demographic feature that population age is growing and the labor market is dominated by family employment.

\section{Environment in the RMG sector}

In the workplace, RMG workers, especially women workers face different type of difficulty and problems in terms of securing the job and work environment. To discuss work environment includes environment in the workplace such as accident and injuries, harassment at workplace, arbitrary appointment, and promotion and dismissal rules. And the environment outside the workplace such as labor market in the cluster areas, access to job, and access to information, social safety net, and negotiation with the factories for their rights. 


\subsection{Accident and injury}

The nature of the accident and injury is mainly twofold: external fire and internal (personal injury). Fire from short-circuits or sabotage is external in nature. Among others, internal accidents in the garment factories include finger-pricking, cuts, collapses included by headache, etc. most of the respondents 60 percent admit that finger cutting and finger pricking happen together at their own workplace while few workers 6 percent mention that due to high pressure of work, sometime they collapse severe headache (Table 6). All these happened due to unhealthy working environment as well as high work pressure since they have to attain production target with in stipulated time, which, even gets worsted because of frequent disruption of work by electricity failure, strike, etc.

\subsection{Working hour, wage payment and incentives and facilities}

According to the CPD-RMG Survey (2006) in most of the sample enterprises, normal working hour (excluding the overtime working hours) was 8.28 hours which was more than working hours set by the law. Normal working hour is high in all categories. From workers point of view, reduction of normal working hour was less important compared to effective working hour, which included overtime working hour along with normal working hour. Regarding the condition of the use by the workers, 18 percent found them excellent, 55 percent mentioned are good condition and 17 percent found them simply acceptable (Table-7). However, the majority 73 percent of the respondent found that the space for working as adequate.

\subsection{Harassment at workplace}

The nature of harassment includes teasing, rough behavior, and using slang (sex related words), while working, proposing sexual relationship, personal abuse, allowing minimum personal space, coercion, etc. fifty percent of the respondents opine that harassments are directly work related. These include scolding 50 percent, transferring from one section to another section 9 percent, reduction of wage 4 percent. The women workers also got sexually harassed and abused 13 percent (Table-8). The respondent s was highly conservative about sexual issues while they were responding.

\subsection{Wage- productivity relation}

According to the CPD-Survey (2006), the gap between worker's productivity and wage level was as high as US\$900 when the early production was taken into account. The gap was higher in Knit Units (US\$1300), followed by woven (US\$750) and sweater (US\$650) units. The gap was much higher in the case of enterprise with relatively a higher productivity such as large (US\$1047). The gap between productivity and wage was relatively less in less productive enterprises, such as small enterprises (US\$740). The workers do not have adequate measures to protect injury in the factory. 68 percent of the respondents report that there is no first aid in their companies. Regarding insurance protection, 98 percent said that there was no such provision in their establishment. The flexibility in maternity and other leaves is also not extended by the RMG companies. In particular, the study shows that $58 \%$ of the workers do not get their sick leave and 65 percent are depriving of maternity leave.

\subsection{Distribution of workers according to their level of skill}

According to the CPD-RMG Survey (2006), level of skill workers 20 percent workers in the sample enterprises belonged to unskilled category; these whole mostly helpers in various section of the factory. The proportion of the semi-skilled workers is about 30 percent, who mainly work as junior operators. Skilled workers are senior operators who comprised of 44 percent of total workers. Professional and management level staff comprised of 5.7 percent of the total labor force. Proportion of the unskilled labor force was relatively low in large enterprises (16-18 percent) while their proportion was higher in medium and small enterprises (18-26 percent); proportion of the skilled worker was to be higher in large enterprises.

In professional positions such as supervisors, floor managers, quality control managers, cutting master, male workers tend to be more preferred; only a few female workers were found to be working as line man and supervisor etc. Female workers thus only cross one to three steps in the job ladder, from helper to senior operator, in the course of their employment. A total of 70 percent of the workers belong to the low skill category even through these women are working for 10 to 20 years, because they are not given any training to enhance their skill (Table 9). The FDG findings reveal that since the owner of the factory is usually a male, they prefer to give promotion to male workers then women workers. Moreover, these garment industries do not follow any labor policies, which would ensure some sort of security of women workers. A total of 50 percent of the respondents belong the secondary education category and 12 percent of the respondents they don't know even how to read and write (Table 10).

\subsection{Labor force participation in South Asia}

The annual data Labor force participation rate, female (\% of female population ages $15-64)$ were drawn from the World Bank, World Development Indicator (WDI-2007, CD-ROM). The data that are used in this analysis are annual, covering the period 1980-2005. The data covers the member of the south asian countries such as Bangladesh, India, Srilanka, Maldives, Bhutan, Nepal and Pakistan. According to the Table-11, demonstrates the female labor force participation rate 
is higher in Bangladesh (61.59 percent) and lower in Pakistan (29.599 percent) compare with the South Asian countries. Pakistan is almost at the lowest in the world ranking in the labor force participation of women and opportunity for women. In the Global Gender Gap Report of the World Economic Forum, Pakistan occupied the 126th position among 128 countries.Table-12 presents the male labor force participation rate is also higher in Bangladesh (89.351 percent) and lower in Maldives (76.548 percent) compare with the South Asian countries.

\section{Conclusion}

Women's workers are active agents of production and the experiences they gain in the process of production do likely to change their market behavior. Women loose opportunities in the labor market, even when they are preferred, because of lack of education and access to information because of socio economic discrimination in the other spheres of life. From this study, we see that women's working condition is not favorable in terms of their social security and economic security. To minimize these risk, the institutional reforms such as regulation and formulation of labor laws is important factors and in order to implement this laws and regulations state and non-state providers should play a catalyst role. Ensuring women workers payment and job security the application of service rule is vital and the accountability of the RMG entrepreneurs should be taken part in to account. Foreign buyers, donors, local, and international stakeholders should also play an active role to ensure labor rigs in their working places.

The provision of general education will also facilitate solving the skill problems of the women's workers largely. Nevertheless, the garment workers are so overworked that they find no time to educate themselves. Hence, intervention is requiring the RMG entrepreneurs to make provision for the workers education and technical training for at least two or three hours a day on alternative days. In addition, it could be initiate health insurance programme for the workers. An early implementation of all these recommendations will surely ease the wage differential problems of the RMG women workers. As result, women workers will improve their life with the help of wage employment.

\section{References}

Alam, M.J, Mamun, M.Z and Islam, N. (2004). Workplace Security of Female Garment Workers in Bangladesh. Social Science Review, Vol.21, No.2, pp.191-200.

Ashenfelter, O. and Oaxaca ,R.L. (1991). Labor Market Discrimination and Economic Development. Unfair Advantage Labor Market Discrimination in Developing Countries, ed. Nancy Birdsall and Richard Sabot, Washington, D.C. The World Bank, pp.35-53.

Barbezat, D.(1993). Occupational Segmentation by Sex in the World. IDP Women/WP-13. Equity for Employment Interdepartmental Project, International Labor Office, Geneva.

Barrientos, S., Kabeer, N. and Hossain, N. (2003). The gender dimensions of the globalization of production. background paper for the World Commission on the Social Dimensions of Globalisation, ILO, Geneva.

Bhattacharya, D. and Rahman, M. (2000). Bangladesh's apparel sector: Growth trends and the post-MFA challenges. Proceedings of a National Seminar on the Growth of the Garment Industry in Bangladesh: Economic and Social Dimensions, BIDS and Oxfam Bangladesh, Dhaka.

Chaudhuri-Zohir, S. (2000). Household Dynamics and Growth of Garment Industry in Bangladesh. Proceedings of a National Seminar on the Growth of the Garment Industry in Bangladesh: Economic and Social Dimensions, BIDS and Oxfam Bangladesh, Dhaka.

Cohen ,Barney and House, William J. (1993). Women's urban labour market status in developing countries: How well do they fare in Khartoum, Sudan. Journal of Development Studies, Vol.29, No. 3, pp. 461 - 483.

Halim, Sadeka (2001). Empowement of Women: The Way Forward, paper presented in a conference organized by Bangladesh Socio Economic Forum in May.

Halim, Sadeka and Kabir, A.H. (2005). Globalization, Gender and Labor Market: Some Evidence from RMG Sector. Social Science Review, Vol.22, No.1, pp.29-44.

Kabeer, N. (2000). The Power to Choose: Bangladeshi Women and Labour Market Decisions in London and Dhaka. London: Verso Publications.

Khundker, N. (2002), Globalisation, Competitiveness and Job Quality in the Garment Industry in Bangladesh, Chapter 3 in Muqtada, M. et al. (eds). Bangladesh: Economic and Social Challenges of Globalisation, study prepared for the ILO Geneva, UPL, Dhaka.

Lim, Linda Y.C. (1984). Labour and Employment Issues in Export Processing Zones in Developing Countries. Lee, Eddy (ed.), op.cit

Mahmud, S. (2003). Is Bangladesh Experiencing a Feminization of the Labour Force, paper presented at the annual meeting of the Population Association of America, Minneapolis, US. 
Oaxaca, Ronald L. \& Ransom, Michael R.,(1994). On discrimination and the decomposition of wage differentials. Journal of Econometrics, Vol.61, No.1, pp. 5-21, March.

Paul-Majumder, P. and Begum, Anwara (2000). The Gender Differentiated Effects of the Growth of Export-oriented Manufacturing: A Case of the Ready-made Garment Industry in Bangladesh, background paper. Washington DC: Policy Research Report on Gender and Development, World Bank.

Paul-Majumder, Pratima (2000). Violence and Hazards Suffered by Women in Wage Employment: A case of women Working in the Export-oriented Garment Industry of Bangladesh. Empowerment, Vol.6.

Quddus, M. and Rashid, S. (2000). Entrepreneurs and economic development: The remarkable story of garment exports from Bangladesh. Dhaka: University Press Limited.

Rahman, Mustafizur, Bhattacharya, Debapriya and Moazzem, Khondaker Golam (2008). Bangladesh Apparel Sector in Post MFA Era: A study on the Ongoing Restructuring process. Dhaka: Centre for Policy Dialogue in association with IFC and SEDF, Qalam Printing press.

Sobhan, Rehman and Nasreen Khundker (2001). Globalization and Gender, Dhaka: The University Press Limited Standing, G.(1981). Globalization Feminization through Flexible Labor. World Development, Vol.17, No.7, pp.1077-1095.

UN (1995). Women in a Changing Global Economy 1994: World Survey on Role of Women in Development. New York: United Nations Department for Policy Coordination and Sustainable Development, United Nations.

\begin{tabular}{|c|c|c|c|}
\hline \multicolumn{4}{|c|}{$\begin{array}{l}\text { Table } 1 \\
\text { Distribution of Female Labor force:1991-2003 (Percent) }\end{array}$} \\
\hline Year & Agriculture & Non-agriculture & Total \\
\hline $1990-1991$ & 33.5 & 66.5 & 100.0 \\
\hline $1995-1996$ & 27.5 & 72.2 & 100.0 \\
\hline $1999-2000$ & 46.9 & 53.1 & 100.0 \\
\hline $2002-2003$ & 58.7 & 42.3 & 100.0 \\
\hline
\end{tabular}

\section{Table 2}

Share of Female Labor Force in Manufacturing Sector:1996-2003

\begin{tabular}{|l|l|l|l|}
\hline Year & Sector & $\begin{array}{l}\text { Women's Share in paid } \\
\text { employment (\%) }\end{array}$ & Women's Share in total employment (\%) \\
\hline $2002-2003$ & Manufacturing & 34.9 & 39.3 \\
\hline $1999-2000$ & Manufacturing & 27.5 & 37.9 \\
\hline $1995-1996$ & Manufacturing & - & 35.5 \\
\hline
\end{tabular}

Table 3

Distribution of Labor force by Skill (Percent)

\begin{tabular}{|l|l|l|l|l|}
\hline Area & Workers Sex & Skilled & Unskilled & Total \\
\hline \multirow{3}{*}{ Rural } & Female & 8.9 & 91.1 & 100.0 \\
\cline { 2 - 5 } & Male & 37.2 & 62.8 & 100.0 \\
\hline \multirow{3}{*}{ Urban } & Female & 11.9 & 88.1 & 100.0 \\
\cline { 2 - 5 } & Male & 34.6 & 65.4 & 100.0 \\
\hline Source: LFS 2000
\end{tabular}




\section{Table 4}

Wage By Sex and Industry: 1999-2000

\begin{tabular}{|l|l|l|l|}
\hline Industry & All & Male & Female \\
\hline Manufacturing & 73.54 & 82.99 & 38.69 \\
\hline Source: LFS 2000
\end{tabular}

\begin{tabular}{|c|c|c|c|}
\hline \multicolumn{4}{|c|}{$\begin{array}{l}\text { Table } 5 \\
\text { Growth Rates of Labor Force and Employment:1991-2003 (Percent) }\end{array}$} \\
\hline Year & Workers Sex & Labor force & Employment \\
\hline \multirow[t]{3}{*}{$1991-1996$} & All & 3.4 & 2.7 \\
\hline & Male & 2.7 & 2.3 \\
\hline & Female & 4.5 & 5.0 \\
\hline \multirow[t]{3}{*}{$1996-2000$} & All & 3.2 & 3.0 \\
\hline & Male & 1.2 & 1.1 \\
\hline & Female & 14.4 & 14.5 \\
\hline \multirow[t]{3}{*}{$2000-2003$} & All & 4.6 & 4.4 \\
\hline & Male & 3.9 & 3.4 \\
\hline & Female & 7.1 & 7.7 \\
\hline Source: LFS & & & \\
\hline
\end{tabular}

\begin{tabular}{|c|c|c|}
\hline \multicolumn{3}{|c|}{$\begin{array}{l}\text { Table } 6 \\
\text { Nature of Accidents at Workplace }\end{array}$} \\
\hline Nature of Accidents & Frequency & Percentage \\
\hline Finger Pricking & 20 & 10 \\
\hline Cuts & 44 & 22 \\
\hline Any combination above & 120 & 60 \\
\hline Collapse injured by headache & 12 & 6 \\
\hline No response & 4 & 2 \\
\hline Total & 200 & 100 \\
\hline
\end{tabular}

\begin{tabular}{|l|l|l|}
\hline $\begin{array}{l}\text { Table } 7 \\
\text { Condition of the Equipments }\end{array}$ & Percentage \\
\hline Condition of the Machines & Frequency & 18 \\
\hline Excellent & 36 & 55 \\
\hline Good & 110 & 17 \\
\hline Acceptable & 34 & 6 \\
\hline Bad & 12 & 4 \\
\hline No response & 8 & 100 \\
\hline Total & 200 & \\
\hline
\end{tabular}




\begin{tabular}{|l|l|l|}
\hline $\begin{array}{l}\text { Table } 8 \\
\text { Nature of Harassment at Workplace }\end{array}$ & \multicolumn{2}{l|}{ Percentage } \\
\hline Nature of Harassment & Frequency & 50 \\
\hline Work related harassment & 100 & 9 \\
\hline Sexual Intercourse & 18 & 4 \\
\hline Personal Abuse & 8 & 13 \\
\hline Combination of above & 26 & 24 \\
\hline No response & 48 & 100 \\
\hline Total & 200 & 4 \\
\hline
\end{tabular}

\begin{tabular}{|l|l|l|}
\hline $\begin{array}{l}\text { Table } 9 \\
\text { Level of skilled women worker }\end{array}$ & Prequency & Percentage \\
\hline Level of skilled & 16 & 8 \\
\hline Highly skilled & 44 & 22 \\
\hline Skilled & 118 & 59 \\
\hline Semi Skilled & 22 & 11 \\
\hline Unskilled & 200 & 100 \\
\hline Total & 22 \\
\hline
\end{tabular}

\begin{tabular}{|l|l|l|}
\hline $\begin{array}{l}\text { Table } 10 \\
\text { Level of education of the respondents }\end{array}$ & Frequency & Percentage \\
\hline Level of education & 24 & 12 \\
\hline Illiterate & 4 & 2 \\
\hline Can signature & 56 & 23 \\
\hline Primary level & 102 & 51 \\
\hline Secondary level (VI-X) & 24 & 12 \\
\hline Higher Secondary & 200 & 100 \\
\hline Total & & \\
\hline
\end{tabular}




\begin{tabular}{|c|c|c|c|c|c|c|}
\hline \multicolumn{7}{|c|}{$\begin{array}{l}\text { Table } 11 \\
\text { Series Name: Labor force participation rate, female (\% of female population ages } 15-64) \\
\text { Descriptive statistics for } 1980 \text { (1) to } 2005 \text { (1) }\end{array}$} \\
\hline Country Name & Mean & Std. Devn & Skewness & $\begin{array}{l}\text { Excess } \\
\text { Kurtosis }\end{array}$ & Maximum & Minimum \\
\hline Banoladesh & 61.595 & 46451 & 0048386 & 17315 & 67850 & 55.194 \\
\hline Bhutan & 37803 & 31835 & 20011 & 41721 & 24411 & 48.751 \\
\hline Pakistan & 29.599 & 1.6837 & 1.0736 & 0.11611 & 33.721 & 27.880 \\
\hline Sri Lanka & 40.845 & 2.4754 & 1.3531 & 1.2447 & 48.193 & 38.074 \\
\hline Nepal & 50.084 & 2.1779 & -0.56410 & -0.85144 & 53.296 & 45.920 \\
\hline Maldives & 29.653 & 8.1873 & 0.92468 & -0.34890 & 49.056 & 20.511 \\
\hline India & 39.988 & 3.8193 & 0.59994 & -1.1105 & 47.115 & 35.988 \\
\hline
\end{tabular}

Source: World Development Indicator, 2007

\section{Table 12}

Series Name: Labor force participation rate, male (\% of male population ages $15-64)$

Descriptive statistics for 1980 (1) to 2005 (1)

\begin{tabular}{|c|c|c|c|c|c|c|}
\hline Country Name & Mean & Std. Devn & Skewness & $\begin{array}{l}\text { Excess } \\
\text { Kurtosis }\end{array}$ & Maximum & Minimum \\
\hline Bangladesh & 89.351 & 0.85864 & -0.40866 & -1.1366 & 90.787 & 87.838 \\
\hline Bhutan & 85.837 & 1.5510 & -1.5719 & 1.3786 & 86.926 & 81.345 \\
\hline Pakistan & 87.330 & 1.5593 & 0.28175 & -1.5147 & 90.182 & 85.453 \\
\hline Sri Lanka & 82.192 & 1.4047 & -0.19173 & -1.1064 & 84.143 & 79.125 \\
\hline Nepal & 83.040 & 2.5483 & 0.76354 & -0.85725 & 88.021 & 80.033 \\
\hline Maldives & 76.548 & 2.6899 & -0.25256 & -1.3091 & 80.123 & 71.615 \\
\hline India & 86.256 & 1.0517 & -0.36121 & -0.88597 & 87.904 & 84.303 \\
\hline
\end{tabular}

